\title{
ポリエチレンの浸水課電現象に及ぼす 液体の効果
}

住友電気工業株式会社 速 水 敏 幸

\section{1. まえがき}

筆者は，さきにポリエチレンに種々の液体を粱布し たり，あるいは吸収させたときの耐部分放笔性，耐卜 リーイング性，交流破䙓電王について検討した結果を 本綎に発表した。 ${ }^{(1)-(3)}$ このようにポリエチレンと液体 上を組合甘大場合の，主として電気的破壊特性につい て一連の実験を行なってきたか，今回はこの中で重 要な特性の一つであるポリエチレンの浸水課電現象之 ての現象に及卧す液体の効果について報告する。

一般にゴム，プラスチックは水代詨する抵抗性が高 い上考觉られているが，単传浸水だけではなく、これに 電圧が加わると劣化が促遥されることが古くから知ら 机ている。我志た，空中 $V-l$ 特性飞対して浸水 $V-t$ 特性のほうが低下が著しいが，このように漫水しかつ

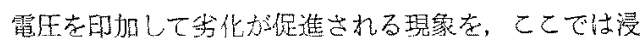
水課電現象または浸水課電劣化と称することにする。

ポリエチレンの浸水課電䍐象の原因については, 倪下氏ら ${ }^{(5)}$ は $1.1 \mathrm{~mm}$ の銅線に厚さ $0.3 \mathrm{~mm} の$ ポリ エチレンを押出被覆したポリエチレン線で害㰤した結 喿，ポリエチレン中の暴物や久樎に水が浸透し，局部

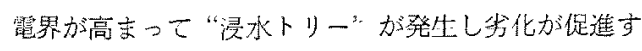
るとしている。

鎌田氏 他方方銅電楆凹場合，銅イオンが触媒乙して促准作用 をするという酸化分化を，吉田氏ら(7)术りエチレン の水中における劣化の主要因は酸化我化であると発表 している。

このように将リエチレンの浸水課電乎化に関するす くれれた発表があるが，特に劣化機棈についてはまだ不

Effect of Liquid on Wet Charge Phenomenon of Polyethylene. By T. HAYAMI, Member, (Sumitomo Electric Industries, Ltd.).

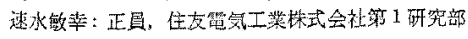

明な点が多い。また，上記実䮖は劣化の判定を主とし て交流破罗電圧の低下の割合で行なっている。

一般に材料の電気的劣化を調べる手段として電左一 時間 $(V-t)$ 特性がよくとられるが, 寿命の推定を行 なう場合，ての特性が最す実際近似している。

ここではポリエチレンの浸水課䉓現象を究明する乎 段しして，構造加簡単で容易に電圧が加けられるポリ エチレンチューブを用い，Vー特性をとった。

感化機構に対しては，特に水之接するポリエチレン の界面江着目し，電位の傾き己 $V-t$ 特性の相関性や 表面に树ける液体の効果の面加引検討した。

\section{2. 実験方法}

实験住メルトインデックスが 1.2 ，密度加 0.92 の 低密度格リエレンのチューブを用いた。チューブは 内径加 $8 \mathrm{~mm}$ て厚さが $1.2,2.0,3.0 \mathrm{~mm}$ と内径加 $4 \mathrm{~mm}$ で厚さが $1.0,2.0,3.0,4.0 \mathrm{~mm}$ の計 7 種類 のものを製作した。

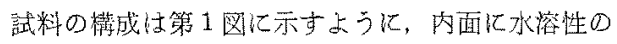
半導電性涳料在放り乾燥させた後, 内径 $8 \mathrm{~mm} の$ 手工 ーブには $2 \mathrm{~mm}$ の7本より(直径 $6 \mathrm{~mm}$ ), 内径 $4 \mathrm{~mm}$ のチューブには $1 \mathrm{~mm} の 7$ 本より (值径 $3 \mathrm{~mm}$ ) の锞 銅線をそう入しケーブルを模擬した。

この試料芜第 2 図(a)《示すように党温水に浸甘き

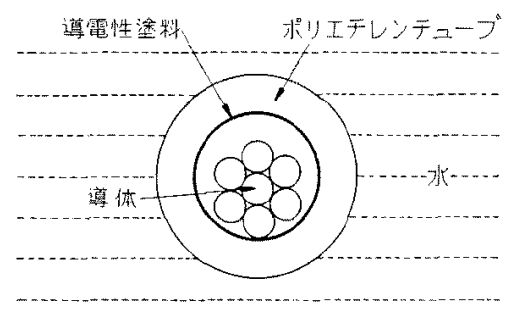

第 1 图 試料心烧面

Fig. 1. Crosssection of sample. 


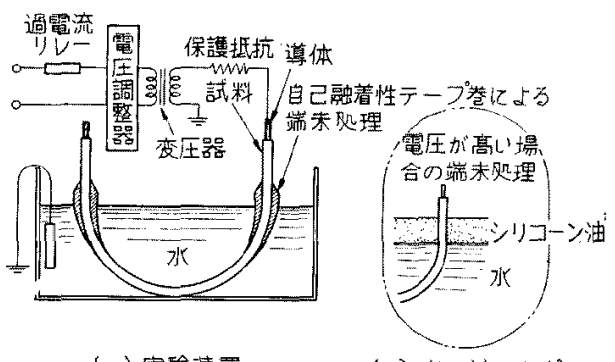

（a）实駼置
(七) 水一油エンド

Fig. 2. Test arrangement.

し，導体に $60 \mathrm{~Hz}$ の交流露圧を印加し破壊するまでの

$V-t$ 特性を調べた。

電圧 1 条件での試料の点数はそれぞれ $3 \sim 5$ 点とし t。

1 本の試料の長さは $1.5 \mathrm{~m}$ で電極となる浸水部の長 さは $0.8 \mathrm{~m}$ でる。電極の端末処理は，主として自己 融着性テープを円すい状に巻いたコーンを設けた。需 功高いクラス（たとえば， $1.2 \mathrm{~mm}$ 厚チューブに20 $\mathrm{kV}$ 以上の電生を印加する禓合）の浸水課電試驗の端 末処理は第 2 図(b)に示すように，水の上にシリコ一 ン油を浮加せた水一油エンド(8)を朋いた。この場合， 水中部のポリエチレンチューブ表面にシリコーン油が 付着しないように詿料を水の中に入れた後, 端末処理 のシリコーン油学浮加せ。

\section{3. 実験結果}

〈3.1〉印加電圧の影響 まず内径 $8 \mathrm{~mm}$ で 1.2 mm 厚のチューブを用いて漫水課麗之空中課電の比較 を行なった。空中課電はチューブの外側に金属はくを 巻いて電極とし空中で課電した。縱軘索印加電王 $V$,

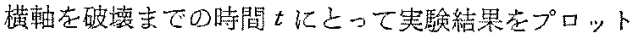

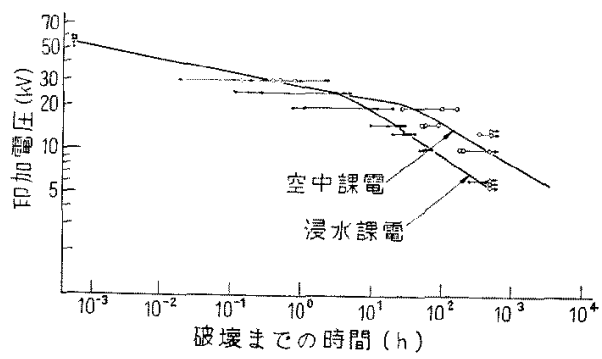

第 3 图 ポリエチレンチューブの漫水課麗 上空中課電

Fig. 3. Wet charge and dry charge of polyethylene tube.

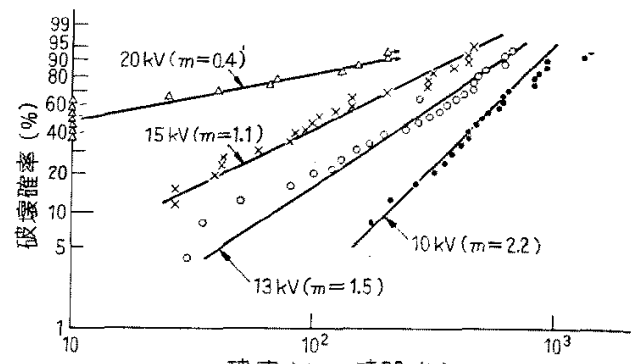

破壇までの時間( (h)

第 4 図 漫水 V-tのワイブル分布

Fig. 4. Weibull chart of wet charge $V-t$ characteristic.

すると第 3 図に示すような $V-t$ 特性が得られた。

この結果から，ポリエチレンチューブの漫水課電と 空中課雷におりる筹命の差は印加電圧が $20 \mathrm{kV}$ 付近 で現われることがわかる。また V-t 特性は，浸水㹎 電と空中課電はともに印加電圧が $15 \sim 20 \mathrm{kV}$ の所で 新机曲がる。

次に同じチューブを用いて浸水課霆現象に及ばす印 加電圧の影響亡破壊の形態を統計的手法によるワイブ 儿分布で調べた。笑験恃印加電圧が $10,13,15,20 \mathrm{kV}$ の4 種類で，それぞれの試料の点数は22〜24 点とっ た。得た結果をワイブル確率緍にプロットすると第 4 図に示すようになる。との結果形のパラメータ $m$ は 印加䉓比によって值が異なり電圧が低いほど大きくな る。

ワイブル分存では故障の発生現象を $m$ の值によっ て分類することができ，一般に

$$
\begin{aligned}
& m>1 \text { のときは摩耤形 } \\
& m=1 \text { のときは偶発形 } \\
& m<1 \text { のときは初期不良形 }
\end{aligned}
$$

とされている。影てれをあてはめるこポリエチレンチ ューブの浸水課電分化低低電生領域に属する $10,13 \mathrm{kV}$

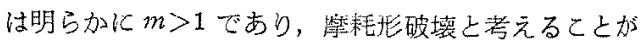
できる。

さらに，印加電王が高くなる領域では $m=1$ または $m<1$ 上なり，初期叔上び偶発的破壊が支配的上なる。 すなわち，高電圧領域では最初から試料纪存在する欠 宿部よりひき起てす破壊が支配的之なり，低電生頒域 では责化が累皘的に進行する破壊之みなすととができ る。长して, 浸水課電と空中課電の差はこの低電圧領 域で起こるととから, 术リェチレンの浸水課電現象を みる赛験は，低電正長時間行なう必要があることがわ かった。その電压山後述する水が接する表面の䉓位の 傾きで，10kV/mm 以下である。 
$\langle 3 \cdot 2\rangle$ 浸水課電と電位の傾き＼cjkstart次にポリエチレ ンチューブの電位の傾きと浸水課電少化の関係を調べ た。試料は终 $8 \mathrm{~mm}$ チューブの $1.2,2,3 \mathrm{~mm}$ 厚と 内径 $4 \mathrm{~mm}$ チューブの $1,2,3,4 \mathrm{~mm}$ 厚の合計 7 種類 のものを用いた。

この試料の上うに同心円筒の場合，遒体半径 $R_{1}$ (

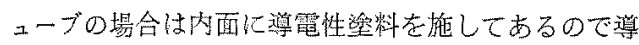
体蓜径はチューブ内径とする)，絶緑体表面までの半 径を $R_{2}$ とす机ば，絶縁体们電圧 $V$ がかかったたき の軸加らrなる距䑾の点の麗位の傾き $E$ は次式で表 わさ机る。

$$
E=\frac{V}{r \log _{R_{1}}^{R_{2}}}
$$

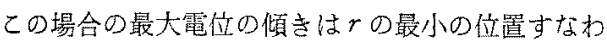
ち $r=R_{1}$ の導体真上であり，最小電位の傾きは $r=$

第 1 表 印加電生と電位の傾き $(\mathrm{kV} / \mathrm{mm})$ Table 1. Applied voltage vs. potential gradient.

上段：最大需位の倪き，下殷：最小䨘位の傾き

\begin{tabular}{|c|c|c|c|c|c|c|c|c|}
\hline \multicolumn{2}{|l|}{ 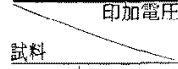 } & $6 \mathrm{kV}$ & $10 \mathrm{kV}$ & $13 \mathrm{kV}$ & $15 \mathrm{kV}$ & $20 \mathrm{kV}$ & $30 \mathrm{kV}$ & $\begin{array}{c}E_{\max } / \\
E_{\min }\end{array}$ \\
\hline \multirow{3}{*}{$\begin{array}{l}\text { 内程 } \\
8 \mathrm{~m} \\
\pm= \\
7\end{array}$} & $1.2 \mathrm{~mm}_{\text {厚 }}$ & $\begin{array}{l}5.7 \\
4.4\end{array}$ & $\begin{array}{l}9.6 \\
7.4\end{array}$ & \begin{tabular}{|r|}
12.5 \\
9.6
\end{tabular} & \begin{tabular}{|l}
14.4 \\
11.1
\end{tabular} & \begin{tabular}{|l|}
19.2 \\
14.8
\end{tabular} & $\begin{array}{l}28.7 \\
22.1\end{array}$ & 1.3 \\
\hline & $2 \mathrm{~mm}$ 原 & - & - & - & $\begin{array}{l}9.3 \\
6.2\end{array}$ & - & - & 1.5 \\
\hline & $3 \mathrm{~mm}$ 幖 & $\longrightarrow$ & - & $\longrightarrow$ & & $\begin{array}{l}9.0 \\
5.1\end{array}$ & $\begin{array}{r}13.4 \\
7.7\end{array}$ & 1.7 \\
\hline \multirow{4}{*}{$\begin{array}{l}\text { 内径 } \\
4 \mathrm{~mm} \\
y_{7}\end{array}$} & $1 \mathrm{~mm}$ & $\begin{array}{l}7.4 \\
4.9\end{array}$ & $\begin{array}{r}12,4 \\
8.2\end{array}$ & - & - & - & - & 1.5 \\
\hline & $2 \mathrm{~mm}$ 厚 & - & $\begin{array}{l}7.2 \\
3.6\end{array}$ & - & - & $\begin{array}{r}14.5 \\
7.2\end{array}$ & - & 2.0 \\
\hline & $3 \mathrm{~mm}$ 厚 & - & - & - & - & $\begin{array}{r}10.9 \\
4.4\end{array}$ & $\begin{array}{r}16.4 \\
6.6\end{array}$ & 2.5 \\
\hline & $4 \mathrm{~mm}$ 檿 & - & 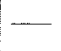 & 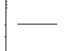 & 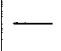 & - & $\begin{array}{r}13.7 \\
4.6\end{array}$ & 3.0 \\
\hline
\end{tabular}

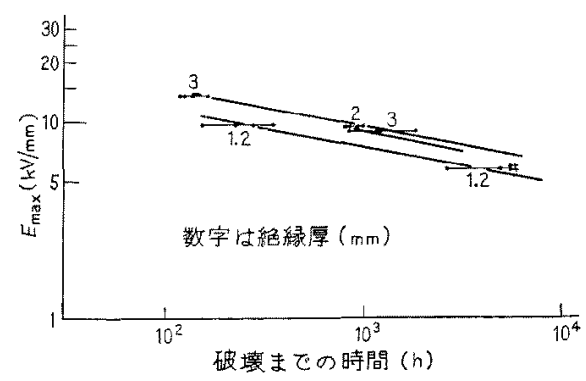

第 5 図 $E_{\max }$ で表示したポリエチレンチューブ の浸水 $V-t$ 特性 (内径 $8 \mathrm{~mm}$ チューブ)

Fig. 5. Wet charge $V-t$ characteristic in $E_{\max }$ of polyethylene tube.
$R_{2}$ の絶緣体表面になる。

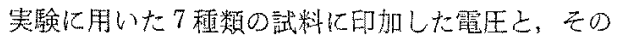

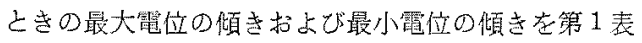
に示す。

内径 $8 \mathrm{~mm}$ チュープの䒠騟絬果走䋛湅に最大電位

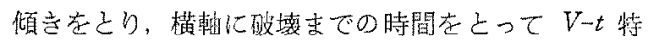
性を表わした場合を第 5 四に示す。

同じくこの結果在緃軸を影小電位の傾き亿とって，

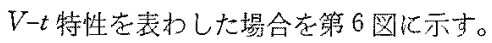

上記両図を比校する上，第 5 図に比へて第 6 图は絶 縁囝の差かなくなり直線状となった。

次に，内径 $4 \mathrm{~mm}$ チューブの热験結果老最大電位の 傾きでプロットした場合学第7図に，最小筐位の傾き でプロットした場合を第 8 図に示す。この結果, 内径 $8 \mathrm{~mm}$ チニーブ上同様に最大電估の傾きの場合心絶緣 厚によって差が現われるが，最小電位の傾きの場合は 絶縁悬にかかわらず各点は洎線上にのる。

このことは，詿料の外側に水がある場合のポリ工千 レンの浸水課電势化による寿命は，水が接している表 面の霸仿の傾きに支配されていることを示している。

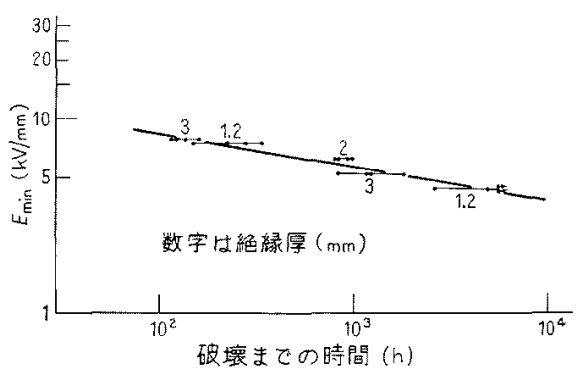

第 6 圈 $E_{\min }$ で表示したポリエチレンチューブ の浸水 $V$ - $t$ 特性 (内径 $8 \mathrm{~mm}$ チューブ)

Fig. 6. Wet charge $V-t$ characteristic in $E_{\min }$ of polyethylene tube.

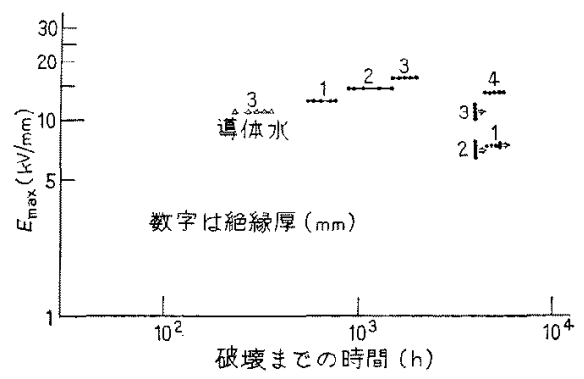

第 7 図 $E_{\text {max }}$ で表示したポリエチレンチュー ブの浸水 $V-t$ 特性 (内径 $4 \mathrm{~mm}$ チューブ)

Fig. 7. Wet charge $V-t$ characteristic in $E_{\max }$ of polyethylene tube. 


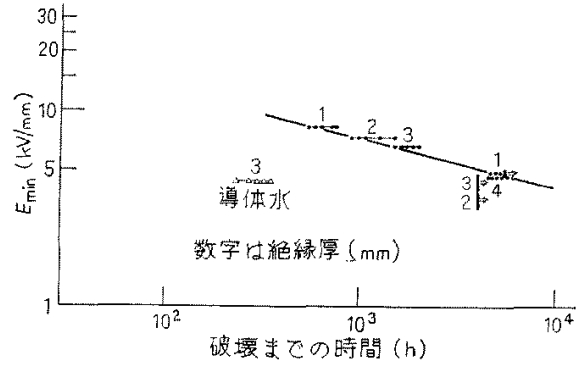

第 8 图 $E_{\min }$ て表示したポリエチレンチュー ブの浸水 $V-t$ 特性 (内径 $4 \mathrm{~mm}$ チューブ)

Fig. 8. Wet charge $V-t$ characteristic in $E_{\min }$ of polyethylene tube.

すねわち，絶縁破壊は水が接している表面が起点と なっていると考えられ，をの部分の電位の傾きが高り れば浸水課電劣化が促進され，寿俞が短くなるといえ る。

また，内径 $8 \mathrm{~mm}$ チューブと内径 $4 \mathrm{~mm}$ チューブの 最大電位の傾きのV-t 特性を比較する上, 同じ絶縁 厚でも内惩 $4 \mathrm{~mm}$ チューブのほうが寿命が長い。とれ は同じ絶縁厚でも内径 $4 \mathrm{~mm}$ のチューブの恬うが水が 按する表面の電位の傾きが小さいからである。また， 最大電位の傾きでブロットした場合の絶縁厚の差は， 内径 $8 \mathrm{~mm}$ チニーブより内径 $4 \mathrm{~mm}$ チューブのほうが 大さいが，最小電位の傾きでプロットすると両万とも 直線になる。すなおち，内径 $4 \mathrm{~mm}$ チューブのほうが 效き方が顕著比現われるわけである。これは最大電位 の傾きと最小電位の傾きの比汃第1表に示すよう に，内径 $8 \mathrm{~mm}$ チューブより内径 $4 \mathrm{~mm}$ チューブのほ うが大きいためである。

次に内径 $4 \mathrm{~mm}$ D $3 \mathrm{~mm}$ 厚チューブは 5 点のみ他の 陚料と異なり，内側に水を入れて $20 \mathrm{kV}$ 印加し浸水 課電莲行なった。すなわち，チェーブの内外に水方存 在する状態とした。実験結果老さきの第 7 図怙よび第 8図にプロットした。

この綕果，内側水ありの場合は外側水上り寿命が短 々、いずれの直線加らむばれる。し加し，乙れを第 9 図に示すように外側水の試料を最小電位の傾きでプ 口ットし，内側水，外側水の試料を最大電位の傾きで

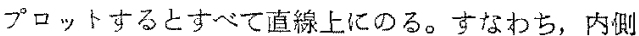
水，外側水の場合は水は雨面に接しているのである 片，絶緣破缺は内側の高いほうのストレスに支配され ることを示している。

したがって，以上の玍験結果加らポリエチレンの浸

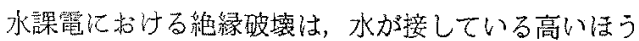

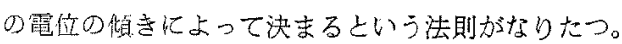

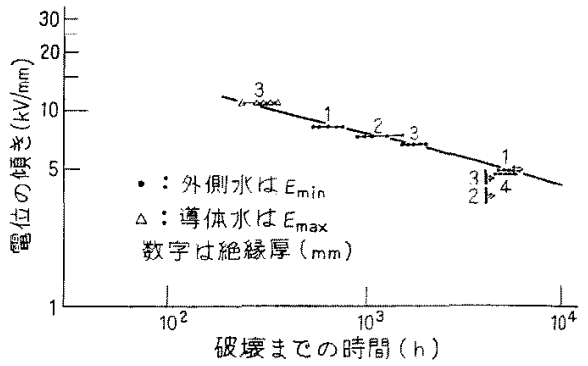

第 9 图 水が接するポリエチレンチニーブ の電位の傾きと浸水 $V-t$ 特性

Fig. 9. Potential gradient of polyethylene tube in contact with water vs. wet charge $V-t$ characteristic.

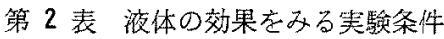

Table 2. Experimental conditions.

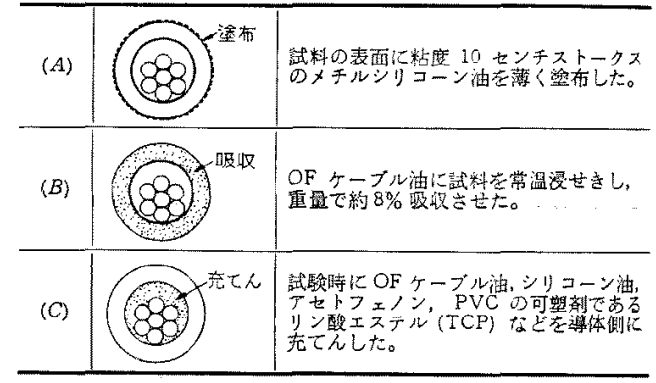

Tabata 氏ら ${ }^{(10)}$ は $6.6 \mathrm{kV}$ の架橋ボリエチレンケー ブルの導侮側に水を入れる亡外側水よりも劣化が促進 すると発表しているが，本実験からこのような現象が 得られたこよがうなずける。

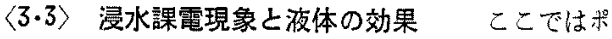
リエチレンチューブの表面に液体荌塱ったり，吸収さ せたり，あるいは，導体側に充てんさせたときの浸水 $V-t$ 特性の実験結果を述べる。実駼はさきに示した内 径 $8 \mathrm{~mm}$ で $1.2 \mathrm{~mm}$ 厚のポリエチレンチューブに， 第 2 表见示す上万条件を施して浸水 V-t 特烧を比 較した。なお，これらの奏験は一展に行なったのでは なく，䄪 5 年の間にそれぞれ別個に行なっているの で、コントールしして入れたオリジナル試料のV-t 特性が若干異なる。こ机は試料の採取場可（口ット間 の牧らつき）や氷温などの冥駼条件の差によるものと 思われる。また，以下の夷堍はすへて外側水の条件で あるので，前飾の結果加らV-t 特性を示すグラフの 縱軸は最小䉓位の傾きでプロットした。

まず，シリコーン油を試料表面に䜃布した $(A)$ の条 件での実験結果を第 10 圂に示す。この結果：シリコ ーン油をでく薄く衰面に塗っただけでオリジナル武料 


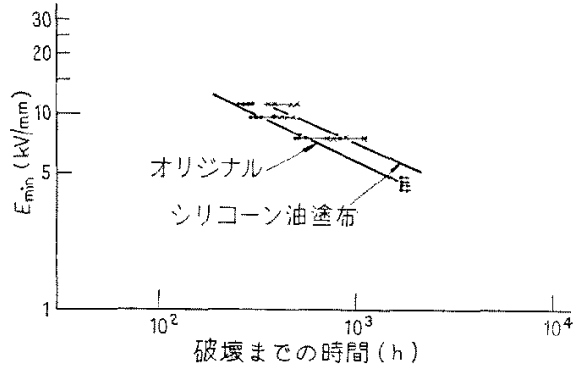

第 10 図 シリコーン油を惉布したポリエチ レンチューブの浸水 $V \omega t$ 特性

Fig. 10. Wet charge $V-t$ characteristic of polyethylene tube with silicone oil coating.

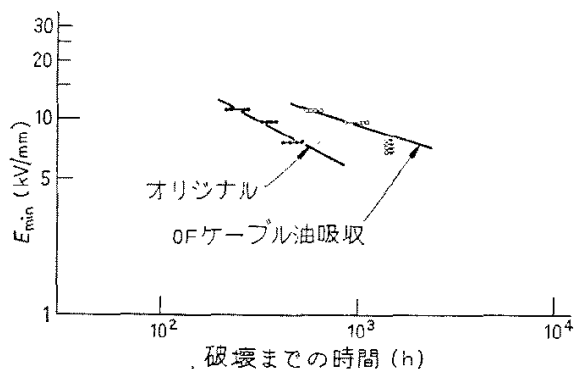

第 11 图 OF ケーブル油を吸彼させたポリ エチレンチューブの浸水 $V-t$ 特性

Fig. 11. Wet charge $V-t$ characteristic of OF cable oil absorption polyethylene tube.

に比べて浸水課電劣化が明らかに㧕制されていること がわ加る。

次に，OF ケーブル油をポリエチレンに吸収させた (B)の条件での実験結果を第 11 図に示すが，この場 合すオリジナル試料に比べ浸水 $V-t$ 特性が向上する。 なお，ポリエチレンに三塩化ジフェニールや鉱物油を 吸収させると，浸水課電娞の公流破壊電压が向上する ことを宮下氏ら ${ }^{(5)}$ がすでに登表しているが，本実験結 果はこれに合致する。

次に試料の尊体側にシリコーン油，OFケーブル油， アセトフニノン，TCPなどの渡体老てんした（C) ○条件での実験結果をまとめて第 12 図に示す。な斿 こ机らの液体交導体唰に充てんした場合，液体の体積 抵抗率はア七トフェノンが $10^{6} \Omega \cdot \mathrm{cm}$ 亡低いが，他の

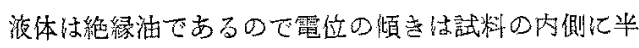

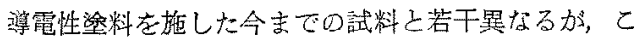
こでは便宜上同一電位の傾きとして报った。

第 12 図の実験結果加ら，これらの液体学導体側に 充てんする己，浸水 $V-t$ 特性が格段に问上すること がわかる。

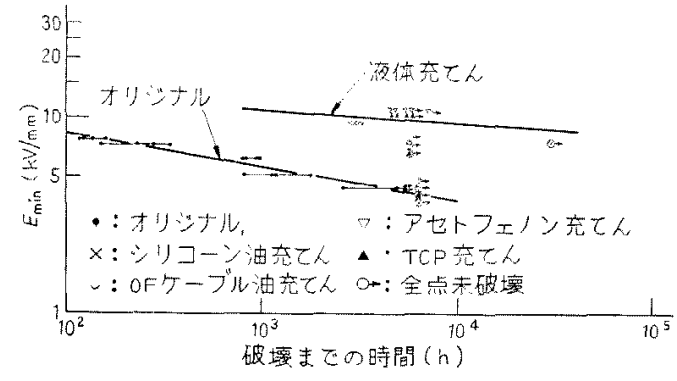

第 12 园 種々の波体を充てんしたポリエチレ ンチューブの漫水 $V \cdot t$ 特性

Fig. 12. Wet charge $V-t$ characteristic of polyethylene tube filled with various liquids.

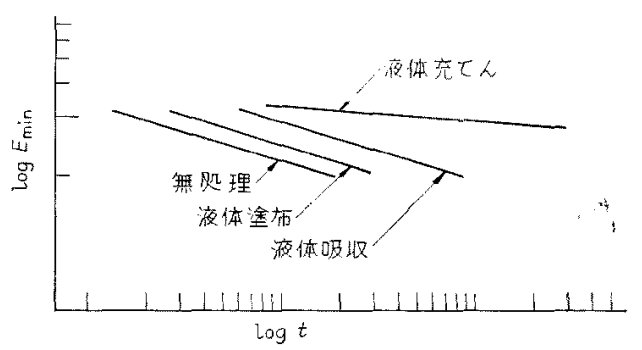

第 13 図 ポリエチレンチューブの浸水 $V-\iota$ 特性に及流す体の効果

Fig. 13. Effect of liquid on wet charge $V-t$ characteristic of polyethylene tube.

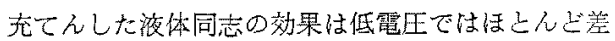
が認められないが，高雪圧付近の結果汃ら順位をつけ ると次のようになる。

$$
\begin{aligned}
& \text { シリコーン油くアセトフェノン, TCP } \\
& \text { <OFヶーブル油 }
\end{aligned}
$$

以上の $(A),(B),(C)$ のおのおのの婪件での害験結 果をまよると，第 13 图化示すようねV-t 特性が 得られる。すなおち，液体を表面に空ったより它絶緑 体に吸取した活うが，さら炕吸収した揚合より尜体组 に充てんした場合のほう汃浸水 $V-t$ 特性加よくなる。

\section{4. 实験結果の考察}

以上の実駼により，ポリエチレンの浸水課電劣化は

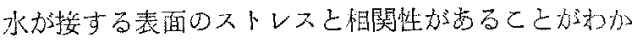

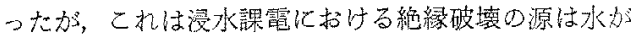
接方る界面加らであるとと者咥している。このこと は，〈3・3〉節の些騟から水が揬する表面にシリコーン

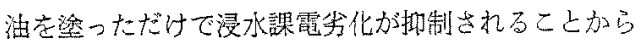
戟明でたと考える。

ここてで，まず漫水課電劣化は表面效果が主体でる

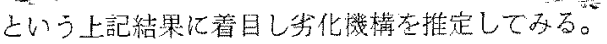


宮下氏ら ${ }^{(5)}$ は浸水課電後のポリエチレン線の表面か ら，または絶縁体中のボイド，異物などからトリー状 の劣化こん跡（浸水トリ一）が発生しているのを観察 している。本実験では全体を通じて上記浸水トリーを 観察する綿密な調査を行なっていないが，1.2mm 厚 試料に $6 \mathrm{kV}$ を約 200 時間課電したすのからはトリー は認められず, 約 1,000 時間課電した試料に表面から あるいはボイドからのトリーが観察された。

第 14 図に $6 \mathrm{kV}, 1,000$ 時間課電試料より钼察され たトリーの写真を示す。浸水トリーの場合は，このよ うに非常に細い管が集まったブッシュ状のトリーとな る。特に表画からのトリーの発生位圆は, 起点からの 管が1本のためか顕微鏡であ見にくい。しかし，との 写真からあ見うけられるように, トリーの起点は表面 のくぽんだ所から発しているととがわかった。

第 15 図にポリエチレンチューブの表面の状態を写 した写真を示す。この写真からあわかるように，ポリ エチレン表面は前記トリーの発生源と見られる凹凸や 傷が多い。こ机らのトリーがいったん出ると次第に伸 び，遂には絶縁破壊の原因となりうることが容易に想 像される。

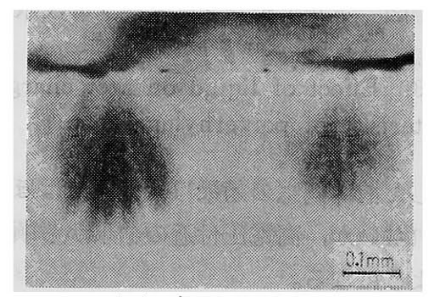

（a）表面加らのトリー

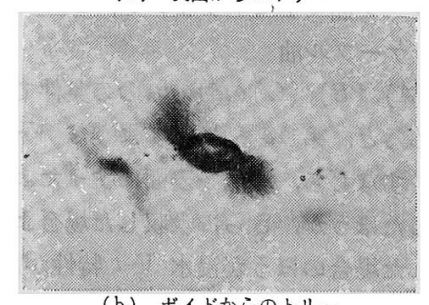

(b) ボイドからのトリー

第 14 図 ポリエチレンチューブのトリー

Fig. 14. Tree of polyethylene tube.

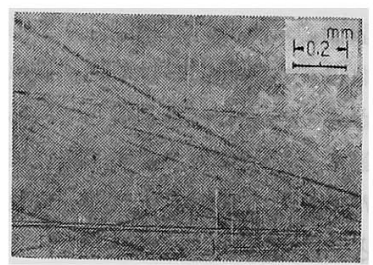

第 15 図 ポリエチレンチューブの表面

Fig. 15. Surface of polyethylene tube.
そとで，ここではそのトリーの発生の原因について 考察することにしたい。このような浸水課電現象は直 流に招いては認められないことを Liddicoat 氏ら(11) および宮下氏ら ${ }^{(5)}$ は指摘していることや，筆者の行な ったポリエチレンの耐部分放電性や耐トリーイング性 に液体の効果があった実験結果などから，浸水トリー 発生の原因は微小部分放電と仮定してみる。ポリエチ レンの耐部分放電性や耐トリーイング性に及ぼす液体 の効果についてはすでに本紙に発表(1)(2) したので，こ こではその結果と考察を簡単に述へる。

ポリエチレンフィルムの表面に種々の液体を塗布し て耐部分放電性を比較した結果，たとえばメチルシリ コーン油や OF ケーブル油のようにポリエチレンにぬ れやすい，または膨潤させやすい液体が効果があると とがわかった。このように表面に液体を塗布して耐部 分放電性が向上するのは，破壊の原因となる部分放電 劣化によってできるピットを液体が埋めるためと考察 した。

次にポリエチレンにアセトフェノン， OF ケーブル 油, シリコーン油などの液体を吸収させ，耐トリーイ ング性を比較した結果，針先にじゅうぶん液体が集ま るような条件で吸収させた場合が最も効果が大きいて とや，電極が導電性ポリエチレンの場合は効果が認め られないととなどがわかった。針端からのトリ一発生 の機構については種々考えられるが，上記実験結果な どから針先の微小空げき内で発生する部分放電と推定 した。

このように液体を施すととによって微小ボイドやピ ットを埋めるという考え方は浸水課電少化に適用でき そうである。すなわち，浸水課電の場合も浸水トリ一 発生の原因は電極である水とポリエチレンとの間に存 在する微小空げきによるものと考えられる。この場合 水とポリエチレンとの間にどの程度の間げきができる か不明であるが, 他の液体に比べると水はポリエチレ ンにぬれにくいことが知られている。

低密度ポリエチレンに対する液体のぬれを投影法に より液滴の接触角を測定した結果, 水の場合は 60〜 $80^{\circ}$ に対して OF ケーブル油およびシリコーン油は測 定ができない (1゚ 以下) ほど小さく，ポリエチレンに 対してきわめてぬれやすいことがわかる。さらに，厚 さ $3 \mathrm{~mm}$ の低密度ポリエチレンに金属針で針状ボイド をあけ，その位置から少し離れた所に液体を滴下し， その広がりによってボイド内に液体が充満するかどう かの実験(1)を行なったところ，水は針状ボイドの上部 にふたのようになり充満しないが, シリコーン油およ び OF ケーブル油などは容易に充満した。 


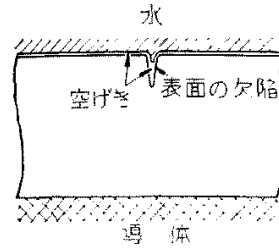

(a)オリジナル

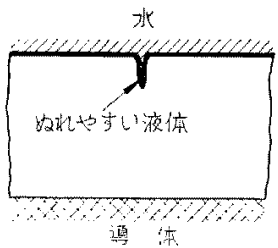

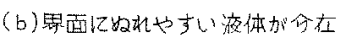

籍 16 图 水とポリエチレンの界面のモデル图

Fig. 16. Enlarged view of surface of poly. ethylene in contact with water.

このように水はポリェチレンに如にくいが，特に 突起状のみぞがあった場合は端部まではいらない。水

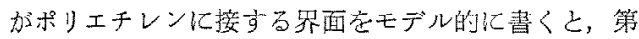

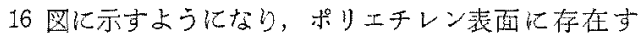
る凸凹，傷などの欠陷部の先端は空げきが残り，部分

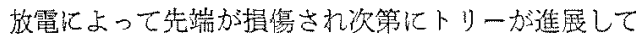
いく本の上考えられる。ぬれやすい液体が界面にある 上，この間げきを埋めるため部分放電が先じない。

夷際にポリエチレンチューブの部分放電在测定した 吕，浸水課電势化が起こっている領域の電正では，2 pC の測定感度の湘定器で测定できなかったので,

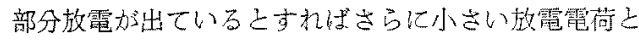
いうことになる。

したがって，浸水課電現象の発生原因が部分放㻨上 いうことを笑証することができないが，今回の実験か ら微小空げきの存在が﨡つけられたこと，浸水卜リ一 発生に時間的効果のあること，直流において認わられ ない己されているこしなどから，筆教は発生原因を德 小部分放雪と考えたい。いずれにして毛，乙れ䒠証 するためにはパッシェンカーブであ古り测是されてい ない大気中における数ミクロンまたはるれ以下の微小 空げきの部分放電の絤部が必要でかる。

次にチューブの奏験で OFケーブル油を䍃縁体に吸 収させた $(B)$ の杀件之，種々の液体学体侧に允てん した（C）の条件にする己浸水 V-も特性が改善された 汃この見象について若えてみる。

上記 2 条件とシリコーン油を表面に潗った $(A)$ の条 件とでは液体が存在する位置が異なり，它の劣化機棈 は前記表面效果だけでは説明が困難となる。そこで， これをわかりやすくするたかにそれぞれの条件におけ

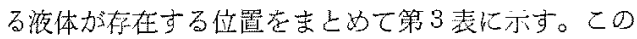
表に扎て，たとえばシリコーン油は常温ではポリエ チレンに吸収されないととは，亦外吸収試娩求上び電 最測定法などで確認しているので，(A)の条件抢よび (C)の条件では絶縁体内には存在しない。

TCP の場合はシリコーン油に比べるとやや吸収き
第 3 表 おの㧍のの実唤に抬ける液体の存在位置

Table 3. Locations of liquid in the tests.

\begin{tabular}{|c|c|c|c|c|c|c|}
\hline & \multirow{2}{*}{ 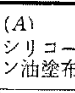 } & \multirow{2}{*}{ 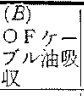 } & \multicolumn{4}{|c|}{ 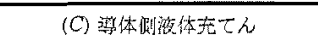 } \\
\hline & & & $\begin{array}{l}\text { シリa } \\
\text {-ン油 }\end{array}$ & {$\left[\begin{array}{l}5+57 \\
x, y\end{array}\right]$} & $T C P$ & $\begin{array}{l}O F \text { T } \\
\text { プルin }\end{array}$ \\
\hline 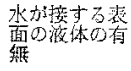 & 符 & (消) & なL & (存) & なL & (有) \\
\hline 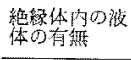 & なし & 有 & なし & 有 & tiL & 有 \\
\hline 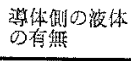 & なし & (有) & 有 & 有 & 有 & 有 \\
\hline
\end{tabular}

れやすいか，常温ではほとんど吸收されない。また， (B)の条件の試料は OFケープル泊在活ぼ飽和するま

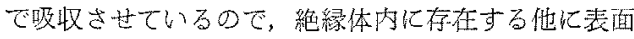
にもわずかににじみててるもの上思的れるアやトフ エノンは常温で約 $3 \%$ ポリエチレンに吸収される。

(B)の条件での試料か（A）の条件交り浸水 $V-t$ 恃 性がまさっていたが，乙れは(A)の条件の他に絶緑体 中のボイド，異物などの弱点部に液体がはいり，この 部分での部分放霆が起こらなくなったためと考えられ る。絶縁体中のボイド，暴物に液体加充渵する機槥

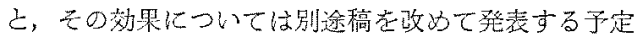
でる。次に(C)の条件のうち，特にシリコーン油を 導体側儿充て几した場合は，絶縁体中に本水と接する 表面に屯液体が存在しないことになるが，てれです浸 水 V-t 特性忧す心扎ている。

筑者は架槅ポリエチレンケーブルの $V-t$ 特性を问 上させるために，電位の傾きの高い導体侧にシリコー ン油を充てんした波体充てん式架撟ポリエチレンケー

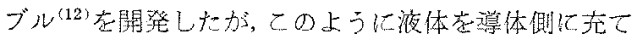

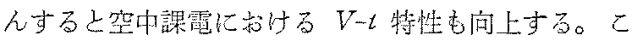

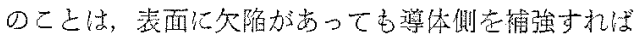
絶䋑破䁲を起しさなくなることを兵している。すなわ ち，杽体侧の補強は表面效果を上回る補強効果がある ことになる。

したがって，以上の結果からポリエチレンの浸水課 電现象の对筷七して考えら札るのは部分的には，(1)

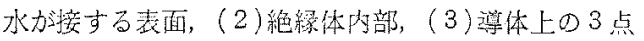
をこれぞ放善することである。その方法は，基本的 には浸水トリーの発生原因上なる表面の凸山, 㑺, 絶 縁体内のボイド異物，算体上の電界不整が起こるよう

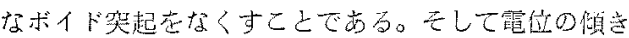

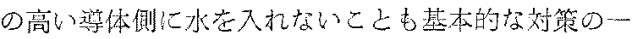
つである。また，補强の一例としては今回実験した滥 体㳊布，吸取，充てんなよ゙の力法が考光られる。

安井氏ら ${ }^{(13)}$ は，架橋ポリエチレンケーブルの外部半

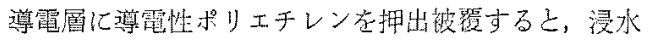


課電劣化が抑制されることを述べているが，てれは， （1）の水上接する表面効果在防いだ方法上思わ扎，乙 の有效性がうなずける。

\section{5. まと}

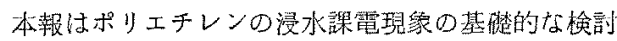
をチューブを用いて重々検討した。実験で得た絬果を 慗約して列記すると次のとおりとなる。

（1）漫水 $V-t$ 特性は高電王領域亡低霞王領域て

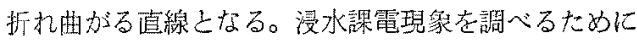
はワイブル分布による摩耗形破塆の領域である低電卮

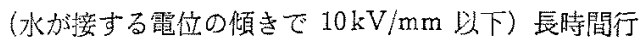
なら必要肪ある。

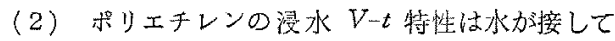
いる表面の電位の傾きに支配される。また，導体側に あ水が存在する場合には尊体側の電位の傾きによって 非命加決まる。

（3） ポリエチレンに液体を施方上浸水 $V-t$ 特性 が向上する。この効果の順位は次のと拈りである。

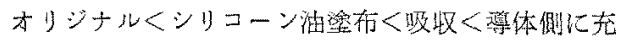
てん
（4）上記結果加ら浸水課瞯現象の発生原因はポリ

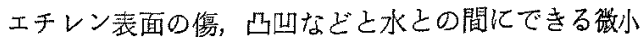
ボイド内の部分放電多化上教察した。

最後に，本研究について有益なご討論とご助言をい ただいた名古屋大学教授家田正之博士に樑く感謝す る次第である。

(昭和 47 年 3 月 4 日受付, 同 47 年 12 月 4 日再受付)

\section{文献}

(1) 速水: 笔学辣 91，1661 (昭 46-9)

(2) 速水: 電学誌 92，343 (昭 47-7)

（3）速水: 電学誌 91, 1917 (昭 46-10)

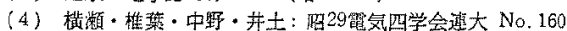

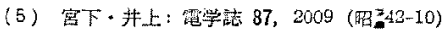

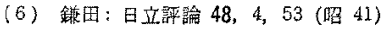

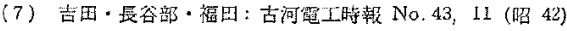

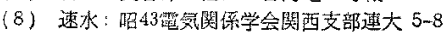

（9）た之元ぱ，日科技連：信賴性ブー夕の解析

(10) T. Tabata, T. Fukuda \& Z. Iwata : IEEE, Transaction Paper 71-TP 545-PWR

(11) C. A. Liddicoat \& B. F. Brown -Wire \& Wire Products p. $1874(1963-12)$

(12) T. Ilayami : IEEE Trans, Fover Apparatus Syst, PAS$88,897(1969)$

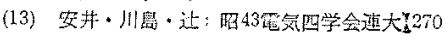

